\title{
REALITA PROFETIK DALAM CERPEN ROBOHNYA SURAU KAMI KARYA A.A NAVIS DAN RELEVANSINYA DALAM PEMBELAJARAN SASTRA
}

\author{
Sri Kusnita \\ IKIP PGRI Pontianak \\ Corresponding Email: srikusnita16@gmail.com
}

Received: 19 $9^{\text {th }}$ September 2020, Accepted: $19^{\text {th }}$ of November 2020, Published: $22^{\text {nd }}$ of December 2020

\begin{abstract}
Abstrak
Penelitian ini bertujuan untuk mendeskripsikan wujud realita profetik dalam cerpen Robohnya Surau Kami Karya A.A Navis. Metode dalam penelitian ini adalah deskrpsi dengan teknik studi dokumenter. Sumber data dalam penelitian ini adalah cerpen Robohnya Surau Kami karya A.A Navis. Dengan demikian data penelitian ini berupa data yang menyangkut fokus penelitian yaitu realita profetik dalam cerpen tersebut. Deskripsi verbal simbol-simbol kebahasaan yang menjelaskan adanya pemaparan realita profetik yang dijadikan data penelitian. Berdasarkan hasil analisis data yang dilakukan dapat disimpulkan beberapa hal sebagai berikut. Pertama, realitas profetik pada asepk humanisasi mencakup aspek (a) manusia yang merasa telah menjadi Tuhan, (b)manusia yang merasa telah menyerahkan nasibnya kepada Tuhan (Tuhan Manusia). Kedua, realitas profetik pada aspek liberasi meliputi aspek, (a) relasi kehidupan spiritual dan realitas sosial, (b) relasi iman, ilmu, dan amal. Ketiga, realitas profetik pada aspek transendensi meliputi aspek pengakuan tentang ketergantungan manusia pada Tuhan.
\end{abstract}

Kata Kunci: realita profetik, pembelajaran sastra, cerpen

\begin{abstract}
This study aims to describe the form of prophetic reality in the short story "Robohnya Surau Kami" by A.A Navis. The method in this research is a description with documentary study techniques. The data source are taken from he story itself. Thus the data of this research is in the form of data concerning the research focus, namely the prophetic reality in the short story. Verbal descriptions of linguistic symbols that explain the prophetic reality are used as research data. Based on the results of the data analysis carried out, several things can be concluded as follows. First, the prophetic reality in the aspect of humanization includes aspects (a) humans who feel they have become God, (b) people who feel that they have surrendered their fate to God (God Man). Second, the prophetic reality in the aspect of liberation includes aspects, (a) the relationship of spiritual life and social reality, (b) the relationship of faith, knowledge, and charity. Third, prophetic reality in the aspect of transcendence includes aspects of recognition of human dependence on God.
\end{abstract}

Keywords: prophetic reality, literature learning, cerpen

Copyright () 2020 Sri Kusnita

\section{PENDAHULUAN}

Cerita pendek (cerpen) sebagai salah satu jenis karya sastra ternyata dapat memberikan manfaat kepada pembacanya. Di antaranya dapat memberikan pengalaman pengganti, kenikmatan, mengembangkan imajinasi, mengembangkan pengertian tentang perilaku manusia, dan dapat menyuguhkan pengalaman yang universal. Pengalaman yang universal itu tentunya sangat berkaitan dengan hidup dan kehidupan manusia serta kemanusiaan. Tema 
cerpen berupa masalah perkawinan, percintaan, tradisi, agama, persahabatan, sosial, politik, pendidikan, dan sebagainya.

Cerpen dengan segala permasalahannya yang universal sangat menarik juga untuk dikaji. Penelitian ini mengkaji cerpen yang berjudul Robohnya Surau Kami karya A.A. Navis. Keistimewaan dari cerpn ini adalah teknik penceritaan A.A.Navis yang tidak biasa pada saat itu. Tidak biasanya karena Navis menceritakan suatu peristiwa yang terjadi di alam lain. Bahkan di dalam cerpen tersebut pengarang menulis dialog antara tokoh manusia dengan Sang Maha Pencipta. Selain itu, cerpen A.A.Navis ini lebih banyak mengingatkan manusia untuk selalu bekerja keras dan menjaga hubungan dengan sesama manusia karena karena hal tersebut merupakan bagian penting dari ibadah.

Cerpen "Robohnya Surau Kami" merupakan kisah yang menjungkirbalikan logika masyarakat awam tentang bagaimana seorang yang dianggap alim justru dimasukan ke dalam neraka. Hal tersebut dikisahkan dalam cerita bahwa seseorang dengan kealimannya orang itu hanya fokus pada ibadah saja sehingga melalaikan kewajibannya sebagai manusia yang harus berinteraksi dengan orang lain yang ada di sekitarnya. Cerpen ini termasuk cerpen yang bertemakan agama (profetik-religius) karena si kakek yang menjadi tokoh utama diceritakan rajin beribadah serta bekerja sebagai penjaga surau.

Semangat profetik dalam karya sastra dipandang penting karena merupakan sentral bertemunya antara dimensi sosial dan dimensi transendental yang terdapat dalam karya sastra. Karya sastra tidak hanya mengacu pada dimensi sosial yang terdeteksi secara indrawi, tetapi juga dunia transendental yang mengacu kepada dunia yang lebih hakiki. Dalam konsteks sastra, profetik dapat diartikan: (1) peringatan akan munculnya kejadian di luar dugaan manusia, (2) prediksi akan kejadian yang bersifat determinan, (3) ungkapan-ungkapan yang bersifat abstrak, dan (4) adanya dialog yang memperlihatkan tanda-tanda awal tentang kejadian yang akan datang (Kuntowijoyo dalam Malay: 1988).

Segi penting dalam sastra profetik adalah tolok ukurnya yang hakiki, yaitu sumber penemuan jati diri manusia kembali dan penyebab tumbuhnya kemungkinan-kemungkinan transendetal. Karya sastra profetik berusaha menampilkan persoalan mendasar yang menyangkut kebenaran. Sastra yang memiliki semangat profetik adalah sastra yang tampil untuk selalu mengingatkan manusia akan Tuhannya, kebaradaan manusia di hadapan Tuhan, dan kesanggupan manusia menerima petunjuk Tuhan (Hadi WM, 1986).

Berdasarkan uraian di atas, cerpen Robohnya Surau Kami menarik untuk dikaji bagaimana profetik sebagai ciri utama fiksi Islmai ditampilkan oleh A.A Navis. Bagaimanakah realitas profetik tersebut dihubungkan dengan keberadaan manusia modern dengan segala 
permasalahan yang ada. Salah satunya yakni permasalahan yang menyangkut identitas diri manusia baik sebagai individu maupun bagian dari lingkungan sosial. Selanjutnya hasil kajian profetik dalam cerpen dapat dijadikan materi ajar pembelajaran sastra pada mata kuliah Kritik Sastra di Perguruan Tinggi khususnya di IKIP PGRI Pontianak, Program Studi Pendidikan Bahasa dan Sastra Indonesia. Materi ajar merupakan suatu materi yang diberikan pendidik kepada peserta didik dalam rangka membantu menguasai suatu kompetensi tertentu. Materi ajar yang digunakan harus tepat agar dapat membantu peserta didik dalam mencapai capaian pembelajaran yang telah ditetapkan.

\section{METODE}

Metode dalam penelitian ini adalah deskrpsi kualitatif dengan teknik studi dokumenter. Alat pengumpulan data dalam penelitian ini adalah penulisan itu sendiri sebagai instrumen utama (kunci). Menurut Ismawati (2013:11) ada beberapa keunggulan manusia dengan instrumen, manusia mampu menangkap makna, interaksinya membuat nilai, lebih-lebih untuk menghadapi nilai lokal yang berbeda dan juga manusia memiliki sifat yang responsif, adaptif, lebih holistik, kesadaran dalam konsep tidak terkatakan, mampu memperoses segera dan mampu mengejar pemahaman yang lebih mendalam. Peran peneliti dalam penelitian ini sebagai instrumen utama, yaitu teknik pengumpulan data dan analisis data secara induktif, bersifat deskriptif dan hasil penelitian lebih menekankan makna, bukan generalisasi oleh peneliti itu sendiri (Nasution, 1996: 12-13; Moleong, 2016: 44). Sumber data dalam penelitian ini adalah cerpen Robohnya Surau Kami karya A.A Navis. Data penelitian ini berupa kalimat atau kutipan yang terdapat dalam cerpen Robohnya Surau Kami karya A.A Navis yang mengandung realitas profetik. Deskripsi verbal simbol-simbol kebahasaan yang menjelaskan adanya pemaparan realitas profetik yang dijadikan data penelitian.

\section{HASIL DAN PEMBAHASAN}

Realitas profetik dalam sastra memuat tiga hal, yaitu humanisasi, liberasi, dan transendensi. Kusdewanti dan Hatimah (2016: 238) menyatakan bahwa akuntabilitas profetik membentuk tiga pilar, yaitu humanisasi, liberasi, dan transendensi. Humanisasi kita perlukan karena ada tanda-tanda bahwa masyarakat kita sedang menuju ke arah dehumanisasi. Dehumanisasi merupakan objektivitas manusia, agresivitas, loneliness, dan spiritual alienation. Dalam dehumanisasi perilaku manusia lebih dikuasai oleh alam bawah sadarnya daripada kesadarannya. Dehumanisasi telah menggerogoti masyarakat Indonesia yang tampak dalam beberapa hal, yakni (1) terbentuknya manusia mesin, (2) manusia dan masyarakat massa, dan (3) budaya massa (Kuntowijoyo (2006:23), 
Liberasi merupakan upaya pembebasan. Pembebasan dalam konsep filsafat dibagi menjadi dua dimensi, yakni (1) bebas dari, dan (2) bebas untuk. Dimensi bebas dari adalah upaya menuntut hak-hak semata. Sementara itu, bebas untuk lebih mengarah kearah pemaknaan kreatif dan positif atas kebebasan yang dimiliki. Ada liberasi dari kekuatan eksternal dan ada liberasi dari kekuatan internal. Pada prinsipnya, kedua kekuatan eksternal dan internal dapat dijadikan tema sastra. Liberasi kekuatan eksternal antara lain: (1) kolonialisme, (2) agresi oleh negara adikuasa kepada negara lemah, (3) kapitalisasi dunia yang menyerbu negara-negara ketiga lewat berbagai rekayasa ekonomi. Liberasi kekuatan internal, antara lain: (1) penindasan politik atas kebebasan seni, (2) penindasan negara atas rakyatnya, (3) ketidakadilan ekonomi, dan (4) ketidakadilan gender (Kuntowijoyo (2006:24),

Kesadaran ketuhanan disebut dengan sastra transendental atau sastra sufi. Transendensi mempunyai makna kesadaran ketuhanan secara agama saja, tetapi juga kesadaran terhadap makna apa saja yang melampaui batas kemanusiaan. Garaudy (1988:34) menjelasakan unsurunsur transedensi ada tiga, yaitu (1) pengakuan tentang ketergantungan manusia kepada Tuhan, (2) ada perbedaan yang mutlak antara Tuhan dan manusia, dan (3) pengakuan akan adanya norma-norma mutlak dari Tuhan yang tidak berasal dari akal manusia. Penuh rasa takut, sangat berharap, pasrah, menerima pemberian Tuhan, syukur, ihklas, dan sebagainya merupakan tema dalam sastra transendental.

Sastra profetik dapat dihubungkan dengan proses perjalanan umat manusia. Pada hakikatnya, proses perjalanan umat manusia terangkum dalam tiga kategori yang menjadi suatu cita-cita, yakni (1) humanisasi, membina kemanusiaan manusia, (2) liberasi, membangun kemajuan kehidupan sosial, dan (3) transendensi, menciptakan kerinduan kepada hidup yang abadi (Kuntowijouyo 1993:288-289). Rumusan cita-cita tersebut juga merupakan aspek tujuan yang dicita-citakan oleh sastra profetik (Norhamsyah, 1994:43).

Berdasarkan hasil temuan dipaparkan pembahasan perihal realitas profetik yang terdapat dalam cerpen Robohnya Surau Kami karya A.A Navis. Pembahasan yang disajikan mencakup tiga aspek, (a) aspek humanisasi, dan (b) aspek liberasi, dan (c) aspek transendensi.

\section{Realitas Profetik pada Aspek Humanisasi}

Tujuan humanisasi adalah untuk memanusiakan manusia yang telah mengalami dehumanisasi. Manusia dilihat secara parsial, sehingga hakikat kemanusian itu sendiri hilang (Syahputra, 2007: 128). Realita profetik pada aspek humanisasi dapat terlihat dalam kutipan sebagai berikut.

"Jika Tuan datang sekarang, hanya akan menjumpai gambaran yang mengesankan suatu kesucian yang bakal roboh. Dan Kerobohan itu 
kian hari kian cepat berlangsungnya. Secepat anak-anak berlari di dalamnya, secepat perempuan mencopoti pakunya. Dan terutama ialah sifat masa bodoh manusia sekarang, yang tak hendak memelihara apa yang tidak dijaga lagi”. (A.A Navis hal. 4)

Dalam kutipan di atas dijelaskan bahwa manusia sudah bersifat dehumanisasi yaitu, tidak menggunakan tempat ibadah untuk beribadah melainkan untuk kesenangan semata. Manusia sudah melupakan tempat suci untuk beribadah dalam agama yang mereka anut karena mereka beranggapan surau tersebut tidak digunakan lagi karena tidak ada penjaganya. Anggapan tersebut sangat bertentangan dengan ajaran agama, yang mengajarkan untuk menjaga kebersihan rumah ibadah adalah tanggung jawab bersama bukan hanya dibebankan pada satu orang saja.

Dalam cerpen Robohnya Surau Kami terdapat sifat manusia yang sombong karena tokoh Haji Saleh beranggapan dirinya lebih mulia dari manusia lain

"Dan di antara orang-orang yang diperiksa itu ada seorang yang di dunia yang dinamai Haji Saleh. Haji Saleh tersenyum-senyum saja, karena ia sudah begitu yakin akan dimasukan ke dalam surga. Kedua tangannya ditopangkan di pinggang sambil membusungkan dada dan menekukan kepala ke kuduk. Ketika dilihatnya orang-orang yang masuk neraka, bibirnya menyungingkan senyum ejekan. Dan ketika ia melihat orang masuk surga, ia melambaikan tangannya, seolah ia ingin mengatakan 'selamat ketemu nanti'. (A.A Navis, hal. 6)

Dalam kutipan di atas pengarang menggabarkan secara jelas sifat sombong manusia. Hal tersebut sering kita jumpai dalam kehidupan nyata bagimana manusia bersikap seolah-olah dia yang paling benar dibanding orang lain.

Cerpen ini memanusiakan manusia dengan memberikan gambaran bahwa orang yang berbuat baik dan banyak melakukan amal ibadah akan memperoleh pahala. Hal tersebut terjadi karena mereka tidak melakukan ibadah dengan ikhlas melainkan untuk kepentingan dirinya sendiri. Tergambar dalam kutipan di bawah ini.

"Alangkah tercengangnya Haji saleh, karena di neraka itu banyak teman-temanya di dunia terpanggang hangus, merintih kesakitan. Dan ia tambah tak mengerti dengan keadaan dirinya, karena semua orang yang dilihatnya di neraka itu tak kurang ibadahnya dari dia sendiri. Bahkan ada salah seorang yang telah sampai empat belas kali ke Mekah dan bergelar syekh pula. Lalu haji saleh mendekati mereka, dan bertanya kenapa mereka di nerakankan semua. Tapi sebagaimana Haji Saleh, orang-orang itupun tak mengerti juga". (A.A Navis, hal. 8)

Penggalan cerita di atas menggambarkan kepada pembaca tentang kehidupan di akherat khususnya neraka yang uman muslim ketahui sebagai tempat penyiksaan orang-orang yang 
telah berbuat dosa di dunia. Namun dalam cerpen tersebut diceritakan tidak hanya orang yang berbuat dosan yang bisa masuk neraka tetapi juga orang yang menggap dirinya sudah melaksanakan perintah Tuhan-Nya dengan taat. Penggalan tersebut mengajak kita untuk merenung bahwa amal ibadah yang kita lakukan di dunia dengan tujuan untuk pamer dan hanya mementingkan diri sendiri belum tentun mendapat balasan masuk surga.

Keegoisan manusia tergambar dalam cerpen tersebut secara tersirat, di mana manausia hanya ingin dianggap suci dengan menelantarkan keluarganya, dia hanya mementingkan diri untuk beribadat kepada tuhan-Nya tampa memperhatikan kehidupan keluarnga sendiri. Padahal dalam agama Isalam diajarkan untuk saling mengasihi sesama manusia, menjaga hubungan baik sesama manusia apa lagi keluarga mereka sendiri. Berikut kutipan cerpen tersebut.

\begin{abstract}
"Kesalahan engkau, karena engkau terlalu mementingkan dirimu sendiri. Kau takut masuk neraka, karena itu kau taat sembahyang. tapi engkau melupakan kehidupan kaummu sendiri, melupakn kehidupan anak istrimu sendiri, sehingga mereka kucar kacir selamanya. Ini kesalahanmu terbesar terlau egoistis. Padahal engkau berkaum, bersaudara semuanya, tapi engkau tak mempedulikan mereka sedikitpun".(A.A Navis, hal. 11)
\end{abstract}

\title{
Realitas Profetik pada Aspek Liberasi
}

Liberasi berasal dari kata liber yang berarti bebas, tidak terikat, dan tidak tergantung. Tujuan liberasi adalah membebaskan manusia dari kekejaman keangkuhan teknologi, dan pemeransan. Kutipan dalam cerpen yang menunjukan aspek liberasi digambarkan sebagai berikut.

\footnotetext{
"Sudah lama aku tak marah-marah lagi. takut aku kalau imanku rusak karenanya, ibadatku rusak karenanya. Sudah begitu lama aku berbuat baik, beribadat, bertawakal kepada Tuhan. Sudah begitu lama aku menyerahkan diri kepada-Nya. Dan tuhan akan mengasihi orangorang yang sabar dan tawakal”. (A.A Navis, hal. 5)
}

Kutipan di atas menggabarkan literasi sang tokoh, bahwa dia sudah terbebas dari urusan duniawi, yang dia kerjakan hanyalah yang berkaitan dengan akhirat saja. Pembebasan diri terhapat hal-hal yang menyenangkan, membebaskan diri suapaya bersikap sabar kerena dia tidak mau alam perbuatannya rusak apabila masih terikat dengan urusan duniawi. Menurut (Efendi, 2012: 81) realitas profetik pada aspek liberasi meliputi aspek, (a) relasi kehidupan spiritual dan realitas sosial, (b) relasi iman, ilmu, dan amal, dan (c) relasi kehidupan berkeluarga, bertetangga, dan bermasyarakat. 
Liberasi adalah upaya pembebasan atau memerdekakan. Dalam konsep filsafat, pembebasan mengandung dua dimensi, yakni (1) bebas dari, dan (2) bebas untuk. Dimensi bebas dari merupakan upaya menuntut hak-hak semata. Sementara itu, bebas untuk lebih menyaran pada pemaknaan kreatif dan positif atas kebebasan yang dimiliki. Ada liberasi dari kekuatan eksternal dan ada liberasi dari kekuatan internal. Pada prinsipnya, kedua kekuatan eksternal dan internal dapat dijadikan tema sastraLiberasi kekuatan eksternal antara lain: (1) kolonialisme, (2) agresi oleh negara adikuasa kepada negara lemah, (3) kapitalisasi dunia yang menyerbu negara-negara ketiga lewat berbagai rekayasa ekonomi. Liberasi kekuatan internal, antara lain: (1) penindasan politik atas kebebasan seni, (2) penindasan negara atas rakyatnya, (3) ketidakadilan ekonomi, dan (4) ketidakadilan gender (Kuntowijoyo (2006:24).

\section{Realitas Profetik pada Aspek Transendensi}

Transendensi sebagai upaya membersihkan diri dengan mengingat kembali dimensi transendental yang letah menjadi bagian dari fitrah kemanusiannya. Transendensi sebagai perjalannan di atas atau di luar melewati batas sekat kemanusian. Menurut Garaudy (1988:34), unsur-unsur transedensi ada tiga, yaitu (1) pengakuan tentang ketergantungan manusia kepada Tuhan, (2) ada perbedaan yang mutlak antara Tuhan dan manusia, dan (3) pengakuan akan adanya norma-norma mutlak dari Tuhan yang tidak berasal dari akal manusia. Dalam Islam transendensi itu akan berupa sufisme. Kandungan sufisme, seperti khauf (penuh rasa takut), raja' (sangat berharap), tawakkal (pasrah), qana'ah (menerima pemberian Tuhan), syukur, ihklas, dan sebagainya adalah tema-tema dalam sastra transendental.

Kutipan yang menjelasakan aspek transendensi dalam cerpen Robohnya Suarau Kami dapat dilihat sebagai berikut.

“Aku mengabdi kepada-Nya?tak kupikirkan hari esokku, karena aku yakin Tuhan itu adadan pengasih dan penyayang kepada umatnya yang tawakal. Aku bangun pagi-pag aku bersuci. Aku pukul beduk membangunkan manusia dari tidurnya, supaya bersujud kepada-Nya. aku sembahyang tiap waktu. Aku puji-puji Dia. Aku baca Kitab-Nya. Allhamdulillah kataku apabila aku menerima karunianya, Astaqfirullah kataku bila aku terkejut. Masyallah kataku bila aku kagum. Apa salah pekerjaanku itu?". (A.A Navis, hal. 5).

Berdasarkan cara berpikir dalam Islam, yang senantiasa berpusat kepada Tuhan dan AlQuran, nilai manusia yang sedalam-dalamnya, dan sesungguhnya akan ditentukan oleh hubungannya dengan Allah SWT, Dzat yang mutlak, dalam rangka hari akhir yang bersifat langgeng dan kekal. Dalam perspektif ini, Tuhan adalah satu-satunya referensi pokok dan mendasar, sebab Tuhan merupakan puncak dan sekaligus tujuan dari sejarah nasib manusia. Manusia menurut Islam merupakan makluk merdeka. Artinya, manusia adalah makhluk yang 
bebas memilih sesuatu dalam hidupnya. Hal itu menjadi suatu penegasan, bahwa jika Tuhan akan memaksakan kehendak-Nya atas manusia, tentulah Tuhan tidak akan membiarkan seorang manusia memilih jalan yang sesat.

\section{Relevansi Realita Profetik dalam Cerpen Robohnya Surau Kami Karya A.A Navis Dalam Pembelajaran Sastra}

Berdasarkan hasil penelitian realita profetik dalam cerpen Robohnya Surau Kami Karya A.A Navis mempunyai relevasi dengan pembelajaran sastra karena relevan dengan capaian pembelajaran dan materi ajar mata kuliah kritik sastra. Relevansi dengan capaian pembelajaran meliputi aspek sikap, pengetahuan, dan keterampilan kesastraan. Menurut Banna (2015: 68) pembelajaran sastra memberikan konstribusi pada keterampilan yang kompleks bagi peserta didik. Melalui pembelajaran sastra peserta didik mampu secara bersamaan menguasai empat keterampilan berbahasa. Moody (1971: 7-10) menyatakan bahwa pembelajaran sastra dapat membantu keterampilan berbahasa, meningkatkan pengetahuan budaya, mengembangkan cipta, dan nilai rasa serta menunjang pembentukan karakter peserta didik.

Hasil penelitian ini relevan dengan capaian pembelajaran berkaitan dengan pertama, aspek sikap, yaitu 1) bertakwa kepada Tuhan Yang Maha Esa; 2) memiliki moralitas, etika, kepribadian luhur, kepedulian sosial tinggi terhadap lingkungan, dan mampu bekerja sama sesuai paradigma profetik; 3) memiliki integritas budaya dan perilaku berkarakter dalam menjalankan tugas dan bekerja; dan 4) mampu mengapresiasi dan mengekspresi karya sastra, serta mengkreasikan karya sastra Indonesia secara lisan dan tulis. Kedua, aspek penguasaan pengetahuan, yaitu 1) menguasai konsep keilmuan sastra yang berkaitan dengan pengembangan materi pembelajaran sastra untuk tujuan mengapresisasi karya sastra secara reseptif, kreatif, dan produktif; dan 2) menguasai konsep keilmuan sastra yang terkait dengan pengembangan materi pembelajaran sastra untuk tujuan mengapresisasi karya sastra secara reseptif, kreatif, dan produktif. Ketiga, aspek keterampilan, yaitu 1) mampu menerapkan teoriteori sastra dalam analisis kesastraan untuk keperluan pembelajaran sastra; 2) menerapkan teori belajar dan pembelajaran dalam pelaksanaan pembelajaran bahasa dan sastra Indonesia.

Hasil penelitian ini relevan dengan materi ajar mata kuliah Kritik Sastra karena pada pokok bahasan mengkaji dan mengkritik karya sastra dengan sub pokok bahasan kegiatan menelaah karya sastra. Tujuan pembelajaran adalah untuk penguasaan bahasa dan sastra secara utuh serta pengembangan pemahaman terhadap nilai yang terkandung dalam sastra. Pemilihan bahan ajar sastra harus memperhatikan perkembangan peserta didik. Merujuk pada hasil penelitian Leubner, dkk. (2016: 30) teks sastra menawarkan pengalaman yang dapat memainkan peran dalam pengembangan pribadi peserta didik dan interaksinya dengan 
masyarakat. Oleh karena itu, pembelajaran sastra dapat dilihat sebagai alat bantu kehidupan peserta didik di masyarakat.

\section{SIMPULAN}

Semangat profetik dalam karya sastra dipandang pentng karena merupakan sentral bertemunya antara dimensi sosial dan dimensi transendental yang terdapat dalam karya sastra. Karya sastra tidak hanya mengacu pada dimensi sosial yang terdeteksi secara indrawi, tetapi juga dunia transendental yang mengacu kepada dunia yang lebih hakiki. Berdasarkan hasil analisis data yang dilakukan dapat disimpulkan beberapa hal sebagai berikut. Pertama, realitas profetik pada asepk humanisai mencakup aspek (1) manusia yang merasa telah menjadi Tuhan, (2) manusia yang merasa telah menyerahkan nasibnya kepada Tuhan (Tuhan Manusia). Kedua, realitas profetik pada aspek liberasi meliputi aspek, (1) relasi kehidupan spiritual dan realitas sosial, (2) relasi iman, ilmu, dan amal. Ketiga, realitas profetik pada aspek transendensi meliputi aspek pengakuan tentang ketergantungan manusia pada Tuhan.

Berdasarkan hasil penelitian realita profetik dalam cerpen Robohnya Surau Kami Karya A.A Navis mempunyai relevasi dengan pembelajaran sastra karena relevan dengan capaian pembelajaran dan materi ajar mata kuliah Kritik Sastra. Relevansi dengan capaian pembelajaran meliputi aspek sikap, pengetahuan, dan keterampilan kesastraan. Hasil penelitian relevan dengan materi ajar mata kuliah Kritik Sastra karena pada pokok bahasan mengkaji dan mengkritik karya sastra dengan sub pokok bahasan kegiatan menelaah karya sastra.

\section{REFERENSI}

Banna, H. A. (2015). Pembelajaran yang Menyenangkan (Editainment) dalam Pengajaran Sastra: Tinjauan pada Metode. Ceudah: Jurnal Ilmiah. 5 (1): 67-76.

Efendi, A.(2012). Realitas Profetik dalam Novel Ketika Cinta Bertasbih Karya Habiburrahman El-Shirazy. Jurnal Litera. 11(1): 72-82.

Hadi, WM. A. (1986). "Semangat Profetik dalam Sastra Sufi dan Jejaknya dalam Sastra Indonesia Modern”. Jakarta: Horison/XXII/1986

Herfanda, A. Y. 2007. “Genre Fiksi Islmai dalam Sastrs Indonesia Mutakhir”. Republika, 4 Maret 2007.

Ismawati, E. (2013). Pengajaran Sastra. Yogyakarta: Ombak.

Kuntowijoyo. (1993). Budaya dan Masyarakat. Yogyakarta: Tiara Wacana.

Kuntowijoyo. (2006). Maklumat Sastra Profetik. Yogyakarta: Grafindo Litera Media.

Kusdewanti, A.I. dan Hatimah, H. (2016). Membangun Akuntabilitas Profetik. Jurnal Akuntasi Multiparadigma. 7(2): 223-239. 
Malay, A. (1988). "Budaya Profetik dan Keterasingan Umat”. Jakarta: Majalah Amanah.

Moleong, J. L. (2016). Metodologi Penelitian Kualitatif (Edisi Revisi). Bandung: Remaja Rosdakarya.

Moody, H.L.B. (1971). Teaching of Literature. Londo: Longman.

Nasution. (2003). Metode Penelitian Naturalistik Kualitatif. Bandung: Tarsito.

Norhamsyah. (1994). "Nuansa Profetik-Dialektis dalam Karya Prosa Kuntowijoyo”. Skripsi tidak diterbitkan. Fakultas Sastra Universitas Gadjah Mada.

Sundari, S., dkk. (1985). Memahami Cerpen-cerpen Danarto. Jakarta: P3B Jakarta.

Syahputra, I. (2007). Komunikasi Profetik: Konsep dan Pendekatan. Bandung: Simbiosa Rekatama Media.

Tarigan, H. G. (1984). Prinsip-prinsip Dasar Sastra. Bandung: Angkasa. 